\title{
AN UNUSUAL SITE OF EPIDERMOID CYST
}

\author{
Jyothi Swarup R ${ }^{1}$ Mohan M², Sathyaki D.C ${ }^{3}$, Mamatarani Rout ${ }^{4}$, Manjunath $\mathrm{K}^{5}$
}

\section{HOW TO CITE THIS ARTICLE:}

Jyothi Swarup R, Mohan M, Sathyaki DC, Mamatarani Rout, Manjunath K. "An unusual site of epidermoid cyst". Journal of Evolution of Medical and Dental Sciences 2013; Vol2, Issue 31, August 5; Page: 5805-5807.

ABSTRACT: Epidermoid cyst is usually due to infection of pilosebaceous gland or due to traumatic migration of epidermis to the deeper structure of skin. They may present in any place of body which is lined by squamous epithelium. They are rarely present in head neck and in oral cavity. We are presenting a rare case of epidermoid cyst presenting in the nasal vestibule.

INTRODUCTION: Epidermoid and dermoid cysts can be present anywhere in the body lined by squamous epithelium. About $7 \%$ occur in head and neck region. The cysts can be defined as epidermoid when the lining presents only epithelium, dermoid cysts when skin adnexa are found, and teratoid cysts when other tissue such as muscle, cartilage, and bone are present. Because of the similar epithelium lining, all three of these cysts may have cheesy keratinaceous material within the lumen. An epidermoid cyst can be differentiated with other sublingual cyst by histopathological examination only ${ }^{1}$.

CASE REPORT: A 55 year old female patient presented with a swelling in the right nasal vestibule since 2 years. The swelling was painless and gradually progressive. Clinical examination revealed a smooth surfaced, non-tender mass $(1 \times 2 \mathrm{~cm})$ with well defined margins in the right nasal vestibule. The swelling was mobile and not fixed to the skin and underlying bone. Clinically swelling in the right nasal vestibule, could be dentigerous cyst or mucocele was suspected.

C.T scan of the nose and paranasal sinuses showed a well defined lesion measuring $1 \times 2 \times 1.5 \mathrm{~cm}$ with cystic component with normal vascularity. It was suggestive of epidermoid cyst. Fine needle aspiration cytology showed sheets of anucleate squamous epithelial cells against a clear background. Features were favouring epidermoid cyst.

The patient underwent excision of the lesion through sublabial approach under local anaesthesia with sedation. The excised mass showed a well circumscribed mass that was attached to the adjacent to the maxilla.

Histopathological examination of the specimen showed fibrofatty tissue and lymphoid aggregates with keratin material. It also showed haemorrhage with inflammatory infiltrate. It was lined by squamous epithelium. It was suggestive of an epidermoid cyst.

DISCUSSION: Epidermoid cysts are lined by stratified squamous epithelium and contain keratin debris. Men are mostly affected and such cysts generally appear after puberty. It is common in young and old, but is rare in childhood. They may be congenital or acquired type. Congenital type is due to entrapment of ectodermal substance between the midline fusion of first and second branchial arches during third and fourth intrauterine life. Acquired type cysts usually occur due to infection around pilosebaceous follicle and sometime deep implantation of epidermis as a result of penetrating or blunt injury. It is slow growing and non tender mass. When present in dermis, it raises epidermis to produce a firm elastic dome-shaped protuberance which is mobile over the deeper structures. They 
grow slowly and may become inflamed and firm time to time. Suppuration may occur ${ }^{1}$. Manoharan etal reported post auricular sinuses are the most common etiology for recurrent post aural abscess followed by dermoid cyst ${ }^{2}$. Ravindranath etal reported epidermoid cyst to be most common in the lateral side of the neck and gingiva followed by the forehead region ${ }^{3}$. Ultrasonography is the best investigation for these types of cyst. It is economical, reliable and without radiation exposure. Surgical excision of the cyst is often required and the entire cyst wall is removed to prevent recurrence. Incomplete removal is common if attempted in the presence of recent infection ${ }^{1}$.

\section{BIBLIOGRAPHY:}

1. Baisakhiya N, Deshmukh P. Unusual sites of epidermoid cyst. Indian journal of otolaryngology and head and neck surgery. 2011 July; 63(1):149-51.

2. Manoharan KS, Saxena SK, Gopalakrishnan S. Congenital anomalies presenting as recurrent post-auricular abscesses: An institution based retrospective study. International journal of pediatric otorhinolaryngology. 2013 June; 5876(13):242-5.

3. Ravindranath AP, Ramalingam K, Natesan A, Ramani P, Premkumar P, Thirevengadam C. Epidermoid cysts: an exclusive palatal presentation and a case series. International journal of dermatology. 2009 April;48(4):412-5

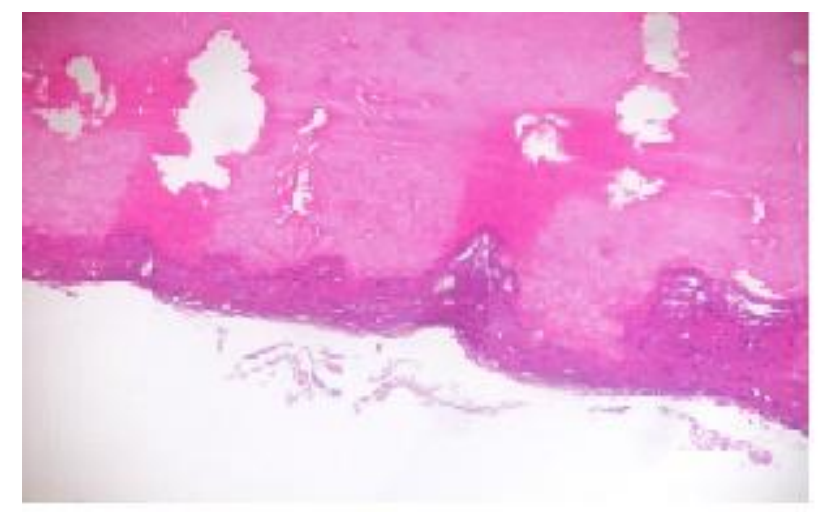

Histopathological Examination

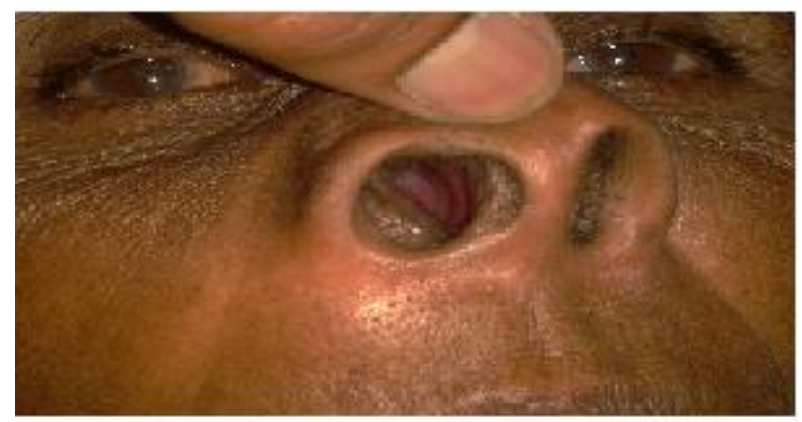

Clinical Picture 


\section{CASE REPORT}

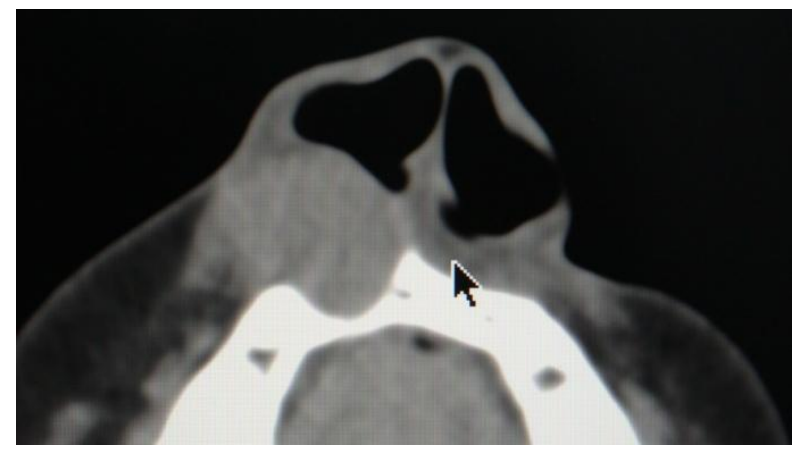

C T Scan

\section{AUTHORS:}

1. Jyothi Swarup. R

2. Mohan. M

3. Sathyaki D.C.

4. Mamatarani Rout

5. Manjunath. K

\section{PARTICULARS OF CONTRIBUTORS:}

1. Associate Professor, Department of ENT, Sri Siddhartha Medical College, Tumkur.

2. Professor, Department of ENT, Sri Siddhartha Medical College, Tumkur.

3. Assistant Professor, Department of ENT, Sri Siddhartha Medical College, Tumkur.

4. Junior Resident, Department of ENT, Sri Siddhartha Medical College, Tumkur.
5. Junior Resident, Department of ENT, Sri Siddhartha Medical College, Tumkur.

\section{NAME ADRRESS EMAIL ID OF THE CORRESPONDING AUTHOR:}

Dr. Sathyaki. D.C., Department of E.N.T, Sri Siddhartha Medical College, Agalakote, B.H. Road, Tumkur - 572107.

Email - sathyaki_dc@yahoo.co.in

Date of Submission: 27/07/2013. Date of Peer Review: 27/07/2013. Date of Acceptance: 31/07/2013. Date of Publishing: 05/08/2013 